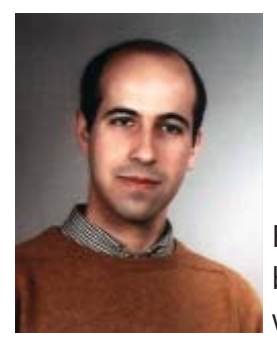

Helder Gomes

bquimica@ipb.pt

www.spq.pt

ano 2010 chega ao fim, é por isso tempo de balanços e de previsões para o novo ano que se aproxima. Se pudermos caracterizar 2010 com uma só palavra, a maioria dos portugueses optarão por "crise". Foi um ano em que a crise económica e financeira mundial fez sentir os seus efeitos mais duros em Portugal, com medidas de austeridade que terão repercussões fortes em 2011 e nos anos vindouros. No que concerne à Química em Portugal, 2010 foi um ano excelente, depois do período de acentuado declínio do número de alunos que se verificou no início da década parece confirmar-se a tendência dos últimos anos da recuperação de alunos a ingressar em cursos superiores relacionados com a Química. Os jovens parecem mostrar um interesse renovado pela Química, os resultados das participações nas várias competições das Olimpíadas de Química coordenadas pela $\mathrm{SPQ}$ assim o confirmam. Pela primeira vez na história das Olimpíadas Internacionais, Portugal obteve um Menção Honrosa, na brilhante participação na prova que se realizou no Japão. Aproxima-se o Ano Internacional da Química 2011 (AIQ2011), com a sua cerimónia oficial de abertura internacional agendada para os dias 27 e 28 de Janeiro em Paris. Será uma oportunidade única, em tempos de crise, para mostrar a grandeza da Química à Sociedade Civil e provar que só por via do desenvolvimento desta ciência se podem ultrapassar os problemas que ameaçam a sustentabilidade do nosso planeta ao nível da alimentação, da saúde, dos recursos energéticos e do ambiente. O próximo ano será também memorável para a SPQ pela comemoração do Centenário da sua fundação. Pela coincidência desta efeméride com o AIQ2011, as comemorações do Centenário da SPQ serão associadas às comemorações do AIQ2011. Entrou em funcionamento no passado mês de Outubro a página oficial portuguesa do AIQ2011 (http://www.spq.pt/quimica2011) onde serão divulgados todos os projectos e actividades relacionadas com as comemorações em Portugal, que terão uma cerimónia oficial de abertura no início do ano e uma cerimónia oficial de encerramento no final do ano. O ponto alto das comemorações será o Encontro Nacional da SPQ, entre 3 e 6 de Julho em Braga. Prepara-se um grande evento, que se espera, o mais participado de sempre.

Neste número do QUÍMICA destacamos os metais do grupo da platina e os complexos de metais de transição com a publicação de dois artigos sobre a história, as propriedades, as aplicações e a importância destes metais para a Sociedade. Surge também uma nova proposta de actividades para o ensino da química, as webquests, recursos potenciadores de pesquisa de informação na Web baseados na resolução de problemas. Com a publicação deste recurso, completamos um ciclo de ferramentas interactivas iniciado no QUÍMICA 117 com os "Roteiros de Exploração" e continuado no QUÍMICA 118 com as "Actividades com os Pais no Computador". Pretende-se continuar este ciclo nos próximos números, desejando-se e incentivando-se contribuições dos nossos leitores nesta área.

Não quisemos deixar passar esta quadra festiva sem oferecer uma prenda ao nossos leitores, o quadro periódico dos elementos químicos com os nomes dos elementos escritos na vertente europeia do português, resultantes do trabalho de uniformização da nomenclatura dos elementos químicos levado a cabo pela comissão composta por portugueses, brasileiros e cabo-verdianos que está a traduzir e adaptar para português, nas vertentes europeia e brasileira, as Recomendações da IUPAC de 2005 da Nomenclatura de Química Inorgânica. Um quadro periódico que apresenta as massas atómicas dos elementos com todos os algarismos significativos que são conhecidos até à data, tornando-o de certeza de grande utilidade para todas as pessoas que necessitam desta ferramenta na sua actividade profissional.

Resta-me desejar a continuação de Boas Festas e que 2011 fique registado na nossa memória, não pelas razões com que iniciei este editorial, mas por muitos sucessos da Química e por uma grande comemoração conjunta do AIQ2011 e do Centenário da SPQ.

Boa leitura!

\section{BOLETIM DA \\ Sociedade Portuguesa DE QuíMICA}

Propriedade de

Sociedade Portuguesa de Química ISSN $0870-1180$

Registo na ERC n. ${ }^{\circ} 125525$

Depósito Legal n. ${ }^{\circ} 51$ 420/91

Publicação Trimestral
N. ${ }^{\circ}$ 119, Outubro - Dezembro 2010

\author{
Redacção e Administração
Av. da República, $45-3 .^{\circ}$ Esq \\ 1050-187 LISBOA \\ Tel.: 217934637 \\ Fax: 217952349 \\ bquimica@ipb.pt \\ www.spq.pt
}

Editor

Helder Gomes

Editores-Adjuntos

Carlos Baleizão, Carlos Folhadela, Joana Amaral, João Paiva

Comissão Editorial

Jorge Morgado, Hugh Burrows,

Joaquim L. Faria, Ana Lobo,

M. N. Berberan e Santos,

A. Nunes dos Santos

Colaboram neste número

o M. Oliveira (HMO), Isabel Vieira (IV),

Maria Filomena Camões (MFC),

Maria Clara Magalhães (MCM), Maria Manuel Marques (MMM), Mariana Sardo (MS),

Paulo Brito (PB), Paulo Ribeiro Claro (PRC),

Sérgio Santos (SS), Vânia Calisto (VC)

$$
\begin{gathered}
\text { Publicidade } \\
\text { Leonardo Mendes } \\
\text { Tel.: } 217934637 \\
\text { Fax: } 217952349 \\
\text { leonardo.mendes@spq.pt } \\
\text { Design Gráfico e Paginação } \\
\text { Paula Martins } \\
\\
\text { Impressão e Acabamento } \\
\text { Tipografia Lousanense } \\
\text { Rua Júlio Ribeiro dos Santos - Apartado } 6 \\
\text { 3200-901 Lousã - Portugal } \\
\text { Tel.: 239 990 260 } \\
\text { Fax: } 239 \text { 990 279 } \\
\text { geral@tipografialousanense.pt } \\
\text { Tiragem } \\
\text { 1800 exemplares } \\
\text { Preço avulso } \\
€ 5,00 \\
€ 18,00 \\
\text { Assinatura anual - quatro números } \\
\text { (Continente, Açores e Madeira) } \\
\text { Distribuição Gratuita aos sócios da SPQ }
\end{gathered}
$$

As colaborações assinadas são da exclusiva responsabilidade dos seus autores, não vinculando de forma alguma a SPQ, nem a Direç̧ão de "Química".

São autorizadas e estimuladas todas as citações e transcrições, desde que seja indicada a fonte, sem prejuízo da necessária autorização por parte

do(s) autor(es) quando se trate de colaborações assinadas.

A Orientação Editorial e as Normas de Colaboração

podem ser encontradas no fascículo

Outubro-Dezembro de cada ano

e no sítio web da SPQ.

Publicação subsidiada pela

FCT Fundação para a Ciência e a Tecnologia

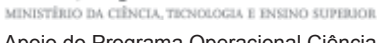

Apoio do Programa Operacional Ciência, Tecnologia, Inovação do Quadro Comunitário de
Apoio III 